\title{
PROF. DR. CEMAL MIHÇIOĞLU'NUN YAŞAM ÖYKÜSÜ
}

Cemal Mihçıoğlu, 9 Eylül 1927'de Gaziantep'in Kilis ilçesinde dơ̆du. Ilkokul ơgretmeni Hasan Fehmi Mihçıoglu ile Nazmiye Mıhçıŏlu'nun ơ̆ludur. Nüfus kayıtlarında 29 Aralık 1927'de doğduğu yazılıdır. flk ogrrenimini 1938 yılında Artvin'in Ardanuç bucağında Adakale tlkokulu'nda tamamladı, orta oğrenimini 1941 yılında Artvin Ortaokulu ve 1944 yılında Gaziantep Lisesi'nde tamamladı. 1944 yılında girdigłi Siyasal Bilgiler Okulu'nu 1948 yılında (Mali Şube) bitirdi.

Zorunlu hizmetle yükümlü oldư̆u Maliye Bakanlığında 1 yıl stajiyer memur olarak çalıştıktan sonra askerlik görevini tamamladı. 1950-1951 yıllarında 6 ay süreyle Çalışma Bakanlı̌̆ı Ankara Bölge Müdürlügüüde Iş Müfettişi Yardımcısı olarak çalıştı.

14/4/1951 günü Ankara Ünivesitesi Siyasal Bilgiler Fakültesi Maliye Asistanlığına atandı. Istanbul Üniversitesi tktisat Fakültesinde yaptı̆̆ı doktora çalışmalarını 1954 yılında sunduğu "Modern Sanayide Beşeri Mulnasebetler" konulu doktora teziyle tamamladi. 29/11/1957'de Siyasal Bilgiler Fakültesi Âmme ldaresi (Kamu Yonetimi) Doçentliǧine, 29/6/1963'te aynı alanda Profesörlǚ̆ge atandı. Docentlik tezi "ABD'de Kadroların Sınıflandırılması," Profesörlük takdim tezi "Idari Reform-Belçika Tecrübesi ve Türkiye Için Alınacak Dersler" konusu uzerineydi.

1951-1953 yılları arasında on sekiz ay süreyle ABD Güney Kaliforniya Üniversitesinin Kamu Yőnetimi Fakültesinde, 1955-1956 yıllarında on iki ay süreyle New York Üniversitesinin Kamu Yơnetimi ve Sosyal Hizmetler Fakültesinde, 1962 yılında beş ay süreyle Belçika'nın başkenti Brüksel'de Uluslararası Yonetim Bilimleri Enstitüsünde, yine o yıl dört ay süreyle Paris'te Direction Générale de l'Administration et de la Fonction Publique'te రğrenim, araşurma, inceleme çalışmalan yaptu.

Türkiye ve Orta Doğu Amme Idaresi Enstitüsünde 1959-1962 yllarında Ö̌rretim Yetiştirme Subesi Müdürlügü, 1965-1968 yıllarında Genel Müdürlük, 1971-1979 yıllarında Milli Prodüktivite Merkezinde Yönetim Teknikleri Danışmanlığı görevlerinde bulundu.

Siyasal Bilgiler Fakültesindeki asıl görevlerine ek olarak başka üniversitelerle yüksek ర̋̌gretim kurumlarında ő̆retim görevi yaptı. Bu arada 1958-1959 ile 1959-1960 ¿ğretim Yıllarında Orta Dogu Teknik Üniversitesi Idari flimler Fakültesinde, 1970-1986 yılları arasında Ankara Üniversitesi Ełitim (Bilimleri) Fakültesinde, 1970-1987 yıllan arasında Ankara Üniversitesi Basın-Yayın Yüksek okulunda, 1983 yılında bu üniversitenin Dil ve Tarih-Cografya Fakültesi Sosyoloji Bolümünde, 1981 ile 1982 
yıllarında Trabzon Iktisadi ve Ticari llimler Akademisinde bir boblümü lisans düzeyinde, bir bollümü lisans üstui düzeyde olmak üzere ợretim görevi yapt.

Üniversiteye oğrenci kaydı ile sınavla oğrenci seçimi konusunda 1960-1961 oğretim yılında Siyasal Bilgiler Fakültesinde yapuğı yeniden düzenleme çalışmaları, bu konudaki kişisel girişimleri üzerine 1962-1963, 1963-1964 yıllarında Ankara Üniversitesinin bütününü kapsayan, 1965 Şubatunda ülkedeki ठbür üniversitelerin de katıldığı "merkezi sistem"in kurulmasıyla sonuçlanmış, bu uygulamanın 1964-1965 ile 1965-1966 öğretim yıllarındaki ilk iki yıllık boblümünü kendisi yőnetmiştir.

TODAtE Genel Müdürluğü sırasında Subat 1967'dé yurttaşlann yơnetimli ilgili sorularını telefonla yanıtlayan Idari Danışma Merkezi'ni kurarak ilk bir yıllık çalışmalarını yakından izleyip bu çalışmalan değerlendiren yayınlar yapmışur.

Yine TODAfE Genel Müdürlüğü döneminde 1965 yılında başlattığı Kırtasiyecilikle Savaş çalışmalan 1965 Ekiminde kurulan yeni hükümetin izlencesinde yer almış kendisinin bu görevden ayrılmasından sonra da sürdürülen bu çalışmalara 1980 sonrası hükümetlerinin izlencelerinde de yer verilmiştir.

Genellikle kamu yönetimi, görevli (personel) konuları, yönetimde insan ilişkileri, kadro sınıflandırması, yönetimde yeniden düzenleme, verimlilik, yönetimde yöntem iyileştirmeleri, yazçizcilikle savaş, kamusal ilişkiler (halkla ilişkiler), işe giriş yanşma sınavlanı; DPT, DPD, TODAlE gibi örgütlerin kuruluşlanyla gelişmeleri; aynca Türkçe'nin özleşmesi, ozzellikle Bau dillerinden dilimize giren terimlere Türkçe karşıllıklar bulunması gibi konularda yayınlar yapmıştır. Úçù çeviri olmak üzere yirmi sekiz kitap, çoğu çeviri olmak üzere 104 gazete yazısı, TODAlE Bülteninde büyüklü küçüklü 135 yazı, onu çeviri olmak üzere 117 dergi yazısı, basılı ya da basılı kapak içinde çoğaltma, broşür niteliǧinde 6 yayını daha vardır.

Ingilizce ve Fransızca bilen Prof. Dr. Cemal Mihçıoğlu Nurten Mihçıoğlu ile evliydi. Nurten-Cemal Mıḩ̧ığlu'nun Umut, Elif, Cem adlı ikisi erkek biri kız ụ̧ çocuklan vardır. 


\section{PROF. DR. CEMAL MIHÇIOĞLU'NUN YAYINLARI}

1. "Kanada'da Kooperatifçilik Hareketi" (A.B. Macdonald'dan çeviri), Karınca (Yıl 18, Sayı 176, Ağustos 1951), sayfa 18-19, (Yıl 1B, Sayı 177, Eylül 1951). sayfa 19-21.

2. $\quad$ "Ingiltere'de Memürların Eğitimi" (F. J. Tickner'den çeviri), AÜ SBF Dergisi (Cilt VII, Say1 1, 1952), s. 262-265.

3. "Amerikan Yardımı ve Kalkınma Meselesi" (Redvers Opie'den çeviri), $A \ddot{U}$ SBF Dergisi (Cilt VIII, Sayı 1-4, 1963), s. 85-97.

4. "Amme Idaresinde Yeni Gelişmeler," (Marshall E. Dimock'tan çeviri), $A \ddot{U}$ SBF Dergisi (Cilt IX, Sayı 1, Mart 1954), s. 59-71.

5. Türk Devlet Teśkilaunda Personelin Yetiştirilmesi (Prof. Dr. J. B. Kingsbury ile birlikte) (Türkiye Orta Doğu Amme Idaresi Enstitüsü yayını) (Ankara: Doğuş Matbaası, 1954), 56 sayfa.

6. Employee Training in the Turkish Public Service (Prof. Dr. J. B. Kingsbury ile birlikte) (Institute of Public Administration for Turkey and the Middle East) (Ankara: Doğuş Matbaası, 1954), 52 sayfa.

7. Insan Davranıst ve Teskilat (H. A. Simon, D. W. Smithburg, V. A. Thompson'dan çeviri) (Ankara: TODAlE yayını, 1954), 54 sayfa (Basılı kapak içinde multigraph'la çogaltılmışır).

"Insan Davranısı ve Teşkilat," Içtimai Emniyet, "Sene 1, Sayı 2, s. 123-132; Sayı 3, Mart 1955, s. 184-208."

Insan Davranısı ve Teşkilat, (TODAtE yayını, Tercüme Serisi 11) (Ankara: Balkanoğlu Matbaacılık Ltd. Şti., 1962); 44 sayfa.

"Insan Davranışı ve Teşkilat," Organizasyonların Beşeri Yönü (Cilt 1) adlı yapıtta (Derleyen: Renato Tagiuri, Atilla Baransel) (Iktisat Fakültesi Işletme Iktisadı Enstitüsü Yayınlan XI (Hüsnütabiat Matbaası, 1966), s. 209-221, 313-325, 701-708.

8. "Türkiye'nin Iktisadi Güçlükleri," Forum (15 Subat 1955), s. 18-19 (22 Ocak 1955 günlu The Economist'ten) (C. M. kısa adıyla).

9. "Türkiye ve Iki Taraflı Ticaret," Forum (15 Şubat 1955), s. 19 (22 Ocak 1955 günlü The Economist'ten) (C. M. kısa adıyla). 
10. "Hür Bir Toplumda Iktisadi llerleme," Forum (1 Haziran 1955), s. 15 (Economic Digest'in Nisan 1955 sayısından) (C. M. kasa adıyla.)

11. Personel Idaresinde Beseri Münasebetler (AÜ SBF Yayınlan, No. 47-29) (Ankara: Son Havadis Matbaası, 1955), XV+247 sayfa.

12. "Çalışma Hayaunda Hümanist Cereyanın Doğuşunu Hazırlayan Içtimai ve Iktisadi Sebepler," Içtimai Emniyet (Nisan 1955, s. 238-239, Haziran 1955, s. 277-288).

13. "Iş̧̧i Maneviyatu," Içtimai Emniyet (Mayıs 1955), s. 268-271.

14. "Türkiye'de Hizmet-içi Eğitimin Islahı Hususunda Tavsiyeler," (J. B. Kingsbury ile birlikte), Içtimai Emniyet (Ekim 1951, s. 509-515).

15. "Amerika'da Fikir Hürriyeti, Üniversite ve Siyaset," Forum (Cilt S, Sayı 49, 1 Nisan 1956), s. 7-8.

16. "Idarede Amirlerle Memur ve Işçiler Arasındaki Münasebetler," $A \ddot{U} S B F$ Dergisi (Yıl: 1954, Sayı 4), s. 85-104.

17. "Memuriyetlerin Siniflandırılması," Idere Dergisi (Y11 28, Mayıs-Haziran 1957, Sayı 246, s. 77-79; Temmuz-Agustos 1957, Sayı 147, s. 181-222) (Bir yüksek yöneticiler semineri dolayısıyla hazırlanan bu yazı, yazarın bilgisi dışında yayınlanmıştır.)

18. "Türkiye'de Amir ve Idarecilerin Hizmet Içinde Yetiştirilmesi ile Ilgili Çalışmalar," AÜ SBF Dergisi (Cilt XII, Sayı 1, Mart 1957), s. 146-162.

19. "Personel Idaresinin Modem Prensipleri ve Devlet Personel Kanunu Tasansı Hakkında Bazı Düşünceler," $A \ddot{U}$ SBF Dergisi (Cilt XII, No. 2, Haziran 1957), s. 86-115.

20. "Türkiye'de Liyakate Göre Terfi Meselesi," AÜ SBF Dergisi (Cilt XII, No. 3, Eylül 1957), s. 90-95.

"Türkiye'de Liyakate Göre Terfi Meselesi," Hazine (Sayı 61, 1 Şubat 1958, Yil 6), s. 6-9.

21. "Personel Idaresi ve Idarede Beşeri Münasebetler," AÜ SBF Dergisi (Cilt VII, No. 4, Aralik 1957), s. 200-210.

22. Amerika Birleşik Devletlerinde Kadroların Sınıflandırılması (AÜ SBF Yayını, No. 82-64) (Ankara: Ajans-Türk Matbaası, 1958), 180 sayfa.

23. Personel Idaresinde Beşeri Münasebetler (Ankara: Ajans-Türk Matbaası, 1958 (Ikinci Baskı), 234 sayfa.

24. Müstakbel Idareciler Için Bir Tahsil-içi Sıaj Programı (H. Yılmaz Günal'la birlikte) (AÜ SBF Yayını, No. 81-731) (Ankara: Ajans-Türk Matbaası, 1959), 84 sayfa.

25. "Türkiye'de Memuriyete Girişte Liyakat Prensibi," A $\ddot{U}$ SBF Dergisi (Cilt XIII, No. 1, Mart 1958), s. 109-116. 
26. "Üniversitelerin Dı̧̧ Öretim ve Teknik Yardım Faaliyetleri" (Lorentz Adolfson'dan çeviri), AU SBF Dergisi (Cilt XIII, No. 2, Haziran 1958), s. 232-239.

27. Türk Amme Idaresi Bibliyografyası (AÜ SBF Yayın,, No. 87-69) (Ankara: Ajans-Türk Matbaası, 1959) (Prof. Albert L. Sturm'le birlikte), 231 sayfa.

28. Bibliyography on Public Administration in Turkey (A publication of the Institute of Administrative Sciences, Faculty of Political Sciences, University of Ankara, Faculty Publication No. 88-70, Institute Publication No. 6). (Ankara: Ajans-Türk Matbaasi, 1959), 224 sayfa.

29. "Devlet Personelinin Hak ve Hürriyetleri," AÜ SBF Dergisi (Cilt XIV, No. 2-3, Temmuz 1959), s. 182-203.

30. "Türk Devlet Teşkilatunda Verimi Artırmak Maksadıyla Personele Sağlanan Maddi Menfaatler," AUU SBF Dergisi (Cilt XIV, No. 4, Aralık 1959), s. 137143.

31. Andre Molitor, "Les Sciences Sociales dans l'Enseignement superieur: l'Administration Publique" (Rapport élabore pour l'UNESCO â la demande de l'Institut International des Sciences Administratives) (UNESCO, Place de Fontenoy, Paris 7e, 1958), 203 sayfa. $A \vec{U} S B F$ Dergisi (Cilt XV, No. 1, Mart 1960), s. 269-300.

32. Cecil E. Goode, "Personnel Research Frontiers" (Public Personnel Association: 1313 East $60^{\text {th }}$ Street, Chicago, Illinois, 1858), 176 sayfa. $A \ddot{U}$ SBF Dergisi (Cilt XV, No. 2, Haziran 1960), s. 217-220.

33. J. J. Ribas, "Les Services de la Fonction publique dans le Monde" (Institut International des Sciences Administratives, Bruxelles, 1956), 168 sayfa. $A \ddot{U}$ SBF Dergisi (Cilt XV, No. 3, Eylül 1960), s. 129-133.

34. Idari Reform ve Reorganizasyon (Komisyon raportorü olarak kaleme alınmışur) (TODAtE yayını, Idari Reform Serisi XII) (Ankara: Balkanoğlu Matbaacılık Ltd. Şti., 1961), 24 sayfa.

35. "Üniversiteye Giremeyenler," Forum (15 Kasım 1961, sayı 153), s. 3-4.

36. Idari Bir Mesele Olarak Üniversiteye Giris Sınavlarının Yeniden Düzenlenmesi - SBF Tecrübesi, Bir Inceleme ve Teklifler (TODAIE yayını, Araşturma Serisi 6) (Ankara: Sevinç Matbaası, 1962), 176 sayfa.

37. "Işletmenin Bir Beşeri Münasebetler Sistemi Olarak Incelenmesi," Sümerbank (Aylık Endüstri ve Kültür Dergisi) (Cilt 2, Sayı 19, Ocak 1963), s. 209-215.

Sümerbank'ın Genel Müdürlük Şube Müdürleri ile Müessese Müdürleri için düzenlenen seminerde yapılan bir konuşmanın metni olan bu yazı, öteki konuşmalarla birlikte aşağıdaki ciltte de yayınlanmışur. Sümerbank Toplu Sözleşme, Grev ve Lokavt Semineri Notları (Ankara, 1963) (Basılı kapak içinde teksir, cilui) (Yazı 18 daktilo sayfasıdır).

38. Idari Reform - Belçika Tecrübesi ve Türkiye için Alınacak Dersler (AÜ SBF yayını, No. 158-140) (Ankara: Sevinç Matbaası, 1963), 136 sayfa. 
39. "Organizasyonun Bir Beşeri Münasebetler Sistemi Olarak Incelenmesi," Organizasyonların Beşeri Yönü (Cilt 1) adilı yapıtta (Derleyenler: R. Taguiri, A. Baransel) (Iktisat Fakültesi Işletme Iktisadı Yayınlan XD, s. 26-31.

"Işyerindeki Ferdi Davranışlann Mekanizması," Organizasyonların Beşeri Yönü, s. 168-180.

"Organizasyonun İ̧yüzü," Organizasyonların Beşeri Yönü, s. 270-284. "Murakabeye Müteallik Meseleler," Organizasyonların Beşeri Yönü, s. 339. 410.

"Gruplararası Münasebetler," Organizasyonların Beşeri Yönü, s. 574-577.

"Iştirak," Organizasyonların Beşeri Yönü, s. 670-688.

40. "Les Services de la Santé publique en Turquie," International Review of Administrative Sciences (No. 2, 1963), s. 127-140.

41. Üniversiteye Giris Sınavlarının Merkezi Bir Sisteme Bağlanması Meselesi (Ankara Üniversitesi yayını) (Ankara: Ankara Üniversitsi Basımevi, 1963), 16 sayfa.

42. "The Civil Service in Turkey," AÜ SBF Dergisi (Cilt XVI, Sayı 1, 1964), s. 89-125.

"The Civil Service in Turkey," Public Administration Review (Journal of the National Institute of Public Administration; 78, Upper Mall, Lahore), (October-December 1963, s. 44-60, January-March 1964, s. 64-85).

"The Civil Service in Turkey," Symposium on Management Training in Public Administration adlı yaym (Central Treaty Organization) (Published by: Office of United States Economic Coordinator for CENTO Affairs, 1964) (Central Treaty Organization, Ankara, Turkey), s. 61-90.

"The Civil Service in Turkey," The Turkish Administrator - A Cultural Survey (Editors: Jerry R. Hopper, Richard I. Levin) (Public Administration Division, US AID, Ankara, Turkey, 1967) (303 sayfa), s. 59-93.

43. Public Relations in Administration - The Influence of the Public on the Operation of Public Administration, excluding Electoral Rights. (Warsaw Round Table, June 1964) (International Institute of Administrative Sciences, Brussels), 46 pages (Mimeographed), (Genel Raportör olarak kaleme almışur).

44. Les Relations Publiques en Matiere Administrative - L'action des administres sur le fonctionnement de l'Administration publique, â l'exclusion du droit électoral. (Table Ronde de Varsovie, Juin 1941 (Institut International des Sciences Administratives, Bruxelles,) 52 pages. (Polycopié (Yukandaki yazanağın Fransızca çevirisi).

45. "Üniversiteye Giriş Sınavlannın Birleştirilmesi," Yeni Orta Oğretim (Haziran 1964), s. 10-11.

46. 1964-1965 Ders Yll Üniversitelerarast Kayıt ve Giris Sınavı Kılavuzu (Ankara: Ankara Üniversitesi Basımevi, 1964), 44 sayfa (Yazar adı konmamışur.) 
47. Unniversitelerarası Giriş Sınavı Uygulama Kuralları (Ankara: Ankara Üniversitesi Basımevi, 1964), 15 sayfa. (Yazar adı konmamışur).

48. Kılavuz - 1965-66 Üniversitelerarası Giris Sınavı (Üniversitelerarası Giriş Sınavı Komisyonu Yayını) (Ankara: Ankara Üniversitesi Basımevi, 1965), 59 sayfa. (Yazar adı konmamışur).

49. Idari Reform ve Reorganizasyon Hakkında On Rapor (TODAlE yayını Türkiye'de Idari Reform Calıșmalan, Idari Reform Serisi XII) (Ankara: Kardes Matbaası, 1965) (Ikinci baskı), 24 sayfa. (Komisyon raportörü olarak kaleme almıştır).

50. Ikametgâh Ilmühaberleri ve Dơ̆ruluk Kâğuları Üzerine Bir Araşıırma (TODAtE yayını) (Ankara: Ankara Üniversitesi Basımevi, 1966), 45 sayfa (Cep boyu)

51. "Okullara Kayıt Formalitesinin Basitleştirilmesi," AÜ SBF Dergisi (Cilt XX, Say1 4, 1965), s. 93-104.

52. "Personel ldaresinde Eğitimin Yeri," Eğitim Yöneticileri Semineri - Raporlar (22 Şubat - 9 Mart 1966) adlı kitapta (Başbakanlık Devlet Personel Dairesi, Yayın No. 14) (Ankara: Başbakanlık Devlet Matbaası, 1967), s. 38-43.

53. Kamu Yönetimi (Birinci Kitap) (H. A. Simon, D. W. Smithburg, V. A. Thompson'dan çeviri (TODAlE yayım) (Ankara: Ankara Üniversitesi Basımevi, 1966), XVI+118 sayfa.

54. "Kayıp Ilanlan Üzerine Bir Inceleme," AÜ SBF Dergisi (Cilt XXI, Sayı 2, 1966), s. 155-166.

55. Prof. Dr. Cemal Mihçıŏlu'nun 1966 yılında Izmir, Adana, Erzurum'da düzenlenen Valiler toplantılarında "Idarenin Yeniden Düzenlenmesi" konusunda yapuğı konuşma, bilgisi dışında ses kuşağından alınarak Türk Idare Dergisinin Ocak-Şubat 1967 sayısında (sayfa 46-57) yayımlanmıştır.

56. "Calhoun Şirketi," Organizasyonların Beşeri Yönü (Cilt 2) adlı yapıtta (Derleyenler: R. Tagiuri, A. Baransel) (tktisat Fakültesi Işletme Iktisadı Enstitïsü Yayınlan XIII) (Istanbul: Hüsnütabiat Matbaası, 1967), s. 95-99. John Desmond Glover ile Ralph M. Hower, The Administrator - Cases on Human Relations in Business (Richard D. Irwin, Inc., Homewood, Illinois, 1954), s. 129-134'ten çeviri.

57. Kamu Yönetimi (tkinci Kitap) (H. A. Simon, D. W. Smithburg, V. A. Thompson'dan çeviri) (TODAlE yayını) (Ankara: Ankara Üniversitesi Basımevi, 1967), $\mathrm{X}+1$ 19-353 sayfa.

58. Türkiye'de Kamu Personeli Sendikaları (Ankara: Ankara Üniversitesi Basımevi, 1968), (Cep Boyu), 135 sayfa.

59. Kamu Yönetimi (Üçüncủ Kitap) (H. A. Simon, D. W. Smithburg, V. A. Thompson'dan çeviri) (TODAlE yayını) (Ankara: Ankara Üniversitesi Basımevi, 1968), [X+355-561 sayfa.

60. Mir Naseem Nahmoud, Satnam Mahmud, "The Case Method and Cases in Pakistan Administration," AÜ SBF Dergisi (Cilt XXIII, Sayı 1, 1968), s. 483-487. 
61. "Development of Senior Administrators in Turkey," AÜ SBF Dergisi (Cilt XXIII, Say1 3, 1968), s. 193-208.

62. "Türkiye'de Yüksek Kademe Yöneticilerinin Eğitimi," AÜ SBF Dergisi (Cilt XXIII, Sayı, 2, 1968), s. 39-71.

63. "Türkiye'de Kamu Personeli Sendikalan," Sevk ve Idare Kursu Ders Notları adlı kitapta (Türkiye Belediyecilik Derneği Yayınlan No. 24) (Ankara: Ayyildız Matbaası, 1969), s. 199-208.

64. "Yơnetimde Insan tlişkileri," Sevk ve Idare Kursu Ders Notları adlı kitapta (Türk Belediyecilik Derneği Yayınlan No. 24) (Ankara: Ayyıldız Matbaası, 1969), s. 139-144.

65. Universiteye Giris ve Liselerimiz (Ankara: Ankara Üniversitesi Basımevi, 1969), XII+227 sayfa. (O yıl içinde bulunan eşi olan ikinci ozel bir baskısı yapılmışur.)

66. "Üniversitelerarası Giriş Sınavında Aldıklan Sonuçlara Göre Türkiye'deki Liselerin Başan Durumlan," AÜ SBF Dergisi (Cilt XXIV, Sayı 4, 1970), s. 57-110.

67. "Prof. Tahsin Bekir Balta'nın Ardından," Cumhuriyet (1 Ağustos 1970), s. 2.

68. "The Application of Information Processing in Turkish Public Administration," $A U ̈$ SBF Dergisi (Cilt XXVI, Say1 2, 1971), s. 79-92.

69. "Halkla Ilişkiler Nedir?" Ankara Üniversitesi Eğitim Fakültesi Dergisi (Cilt 3, Sayı 1-4, 1971), s. 91-108.

70. "Halkla flişkiler Nedir?" Halkla Ilişkiler Semineri (MPM yayını, No. 108, Ankara, 1971), s. 11-28.

71. "Halkla Ilişkiler Nedir?" Işveren (Cilt IX, Sayı 11, Ağustos 1971), s. 3-6, 26-31. (Yazı, Türkiye tşverenler Sendikası Konfederasyonunca yayımlanan bu dergide yazann bilgisi dışında basılmışur).

72. "Halkla flişkiler'de Araştırma," AÜ SBF Dergisi (Cilt XXVI, Sayı 2, 1971), s. 93-106.

73. "Memur Aylıklan ve Verimlilik," Verimlilik (Milli Prodüktivite Merkezince yayımlanan aylık bülten) (Cilt 1, Sayı 2, Ocak 1972), s. 1, 7.

74. "Halkla Ilişkiler," 72 BYYO - BYYO 71-72 Mezunlar Albümü (Ankara: Ajans-Türk Matbaacılık Sanayii).

75. Daha lyi Bir Kamu Hizmeti lçin - Siyasal Bilgiler Fakultesi Üzerinde Bir Araştırma (AÜ SBF yayını, No. 336) (Ankara: Ankara Üniversitesi Basımevi, 1972), 404 sayfa.

76. Eğitim Planlaması Nedir? (Philip H. Coombs'un UNESCO International Institute for Educational Planning'in çıkardığı Fundamentals of Educational Planning dizisinin ilki olarak basilan What is Education Planning? adlı yayınından -1970- çeviri) (Milli Eğitim Bakanlığı Talim ve Terbiye Dairesi Yayınlan, 19 - Eğitim Planlaması llkeleri Serisi, 1) (Ankara: Milli Eğitim Basımevi, 1973), XII+48 sayfa. 
77. Kamu Yönetimi (H. A. Simon, D. W. Smithburg, V. A. Thompson'dan çeviri) (AÜ SBF yayını, No. 354, Cumhuriyetin 50. Yılı Yayınlan, Sayı 9) (Ankara: Ankara Üniversitesi Basımevi, 1973), XVIII + 570 sayfa. (Gozden geçirilmiş ikinci baskı).

78. "Dünya Üniversitelerinde Hastane Yönetimi Eğitimi ve Türkiye," 50. Yıla Armağan (Ankara Üniversitesi Eł̧itim Fakültesi Yayınlan, No. 36) (Ankara: Kalite Matbaası, 1973), s. 15-46.

79. Gelişmekte Olan Ulkelerde Isletme Planlaması (UNIDO'nun PI/44 kodlu, "A Systems Approach to the Introduction aid Use of Corparate Planning in the Developing Countries" başlıklı yayınından çeviri) (Milli Prodüktivite Merkezi yayını, Yonetim ve Verimlilik Teknikleri Dizisi: 1) (Ankara: Ankara Üniversitesi Basımevi, 1974), 53 sayfa. (Cep boyu).

80. "Kamu Yönetiminde Verimlilik," Verimlilik Dergisi (Milli Prodüktivite Merkezi yayını) (Cilt 3, Sayı 1, Ekim-Aralık 1973), s. 5-18.

81. "Gerçek Verimlilik Bunalımı Kamu Yönetimindedir," Verimlilik Dergisi (Richard S. Rosenbloom'un Harvard Business Review'nun September 1973 sayısında yayınlanan Real Productivity Crisis is in Government başliklı yazısından çeviri) (Cilt 3, Sayı 1, Ekim-Aralık 1973), s. 19-30.

82. "Verimlilik Artıncı Özel ve Kamusal Insangücü Politikaları," Verimlilik Dergisi (Eli Ginzberg'in. J. W. Kuhn, B. G. Reubens'le birlikte yazdı̆̆ı!, ABD Devlet Basımevi'nin 0-461-718 sayılı yayın olarak basılan Private and Public Manpower Policies to Stimulate Productivity başlıkłı broşürün çevirisi) (Cilt 3, Sayı 1, Ekim-Aralık 1973), s. 31-54.

83. Üniversiteye Girişin Yeniden Düzenlenmesi - Bugünkü Durum ve Öneriler (Ankara Üniversitesi Eģitim Fakültesi Yayınlar, No. 40) (Ankara: Ankara Üniversitesi Basımevi, 1974), 57 sayfa.

84. Kamu Yönetimi (H. A. Simon, D. W. Smithburg, V. A. Thompson'dan çeviri) (AÜ SBF yayını, No. 354) (Ankara: Ankara Üniversitesi Basımevi, 1975), XVIII + 575 sayfa. (Gözden geçirilmiş üçüncü baska).

85. Isse Giriş Yarışma Sınavları: 1965-1974 - Çeşitli Ögrretim Kurumlarının Başan Durumlan Üzerinde Karşılaşurmalı Bir Araştırma (Ankara Üniversitesi Eğitim Fakültesi Yayını, No. 52) (Ankara: Ankara Üniversitesi Basımevi, 1976), 76 sayfa.

86. "Üniversiteye Giriş Sınavına Katlan Aday Sayısını Sınırlama Zorunluluğu," Ankara Üniversitesi Eğitim Fakültesinin Onuncu Yılına Armağan: 19651975 (Onuncu Yil Yayınları, No. 2) (Ankara: Ankara Üniversitesi Basımevi, 1976), s. 9-21.

87. "Kamusal llişkiler Nedir?" Kamu Kuruluşlarında Halkla Iliskiler Sorunları Semineri başlıklı kitapta (Millı Prodüktivite Merkezi yayım) (Ankara, 1976), s. 11, 29.

(Prof. Dr. Cemal Mıhçıŏlu seminerin sonundaki "panel" tarışmalannı da yơnetmiş, bu taruşmaların seskuşağı çözümlerini de yayıma hazırlamışur. Bu metinde de kendisinin konunun çeşitli yőnlerine ilişkin açıklamaları yer almaktadir. Bkz.: s. 108-147). 
88. "Yönetim, Yöneticilik," Kamu Iktisadi Teşebbüslerinin Yönetim Sorunları başlkklı kitapta (Milli Prodüktivite Merkezi yayını) (Ankara, 1976), s. 127140.

(Yazı, 13-15 Ocak 1976 günlerinde Ankara'da Kamu Kktisadi Teşebbüsleri Üst Düzey Yöneticileri için düzenlenen seminerde yapılan konuşmanın metnidir. Sőz konusu yayında, ayrıca, bu konuşmadan sonra yapılan tartışmalarla konuşmacıya yöneltilen soruların karşıllklarını da içeren bir metin yer almaktadır: Bu metin de tartş̧malann seskuşağı çözümlerinin Profesőr Mihçıŏlu'nca düzeltilip baskıya hazırlanmış biçimidir, s. 127-140).

89. "Daha lyi Bir Kamu Hizmeti Için ve Işe Giriş Yarışma Sınavlan," Toplumsal Yapıyla tlişkileri Açısından Türkiye'de Mülki tdare Amirlił̧i - Sistem ve Sorunlar (Editorr: Doç. Dr. Kurthan Fiş̧ek) (Türk Idareciler Derneği Bilimsel Araşturma Dizisi 1) (Ankara: Ayyıldız Matbaası, 1976), s. 383-400.

90. "Üniversiteye Giriş Sınavlan Öğrenci Seçmede Ne Derecede Geçerlidir?" Yüksek Ögretime Giris Sorunları, (Türk Eğitim Derneği Yayını, TED I. Eğitim Toplantusı: 25-26 Ekim 1977, Ankara) (Ankara: Safak Matbaası, 1978), (244 sayfa) s. 168-173, (Panel bildirisi).

91. Eğitimde Yörelerarası Dengesizlik (AÜ SBF yayını, No. 439) (SBF Basın ve Yayın Yüksek Okulu Basımevi, Ankara, 1980), 46 sayfa.

92. "Eğitimde Yörelerarası Dengesizlik," Eğitim ve Bilim (Mart 1980, Cilt 4, Sayı 24), s. 7-9.

93. Kamu Yönetimi (H. A. Simon, D. W. Smithburg, V. A Thompson'dan çeviri) (AÜ SBF yayını, No. 446) (Ankara: Ankara Üniversitesi Basımevi, 1980), XVI+404 sayfa (Gözden geçirilmiş dordüncü baskı).

94. Bir Kamusal llişkiler Ornekolayı - Ay Adlan ya da Türk Dil Kurumu (AÜ SBF yayını, 474, 100. Doğum Yılında Atatürk'e Armağan Dizisi, 17) (Ankara: SBF Basın ve Yayın Yüksek Okulu Basımevi, 1981), VIII+86 sayfa.

95. "Personel Yasası Düzenlemeleri Kaçınılmazdı," Yankı (Sayı 583, 31 Mayıs 6 Haziran 1982), s. 12.

96. "Yurttaşın Yơnetimle llgili Sorularının Yanıtlanması," $A U ̈$ SBF Dergisi (Cilt XXXVII, Sayı 1-2, Ocak-Haziran 1982), s. 93-113.

97. "Devlet Planlama Örgütünün Kuruluş Günleri," Prof. Dr. Fadıl H. Sur'un Anısına Armaz̆an (AÜ SBF yayını, No. 522, 1983), s. 229-257.

98. "Cok Sanıklı Davalarla Ilgili Bir Yöntem Sorunu: Yassıada Deneyi," $A U U$ SBF Dergisi (Cilt XXXVII, Say1 3-4, Eylül-Aralık 1982), s. 1-22.

99. Ozkaynakça-Bir Deneme (Ankara Üniversitesi Siyasal Bilgiler Fakültesi Yayınlan, No. 524) (AÜ Siyasal Bilgiler Fakültesi Basın-Yayın-Yükssek Okulu Basımevi, 1983), v+184 sayfa.

100. "Türkiye'de Yơnetime Katılma," Ankara Üniversitesi Siyasal Bilgiler Fakültesi Dergisi (Cilt XXXVII, Sayı 1-4, Ocak-Aralık 1983), sayfa 115122. 
101. Kamu Yönetimi (H. A. Simon, D. W. Smithburg, V. A. Thompson'dan çeviri) (Ankara: Ankara Üniversitesi Siyasal Bilgiler Fakulitesi Yayınlan, No. 547), $x \times 1+490$ sayfa.

102. "Dava Dosyalan Üzerinde Bir Araşurma," Ankara Üniversitesi Siyasal Bilgiler Fakültesi Dergisi (Cilt XL, Sayı 1-4, Ocak-Aralık 1985), sayfa 121142.

103. Bir Yönetim Deneyi - Idari Danışma Merkezi, Kırtasiyecilikle Savaş (Ankara Üniversitesi Basımevi) (AÜ Siyasal Bilgiler Fakültesi Yayını: No. 564), $1 x+215$ sayfa.

104. "Basın-Yayın Alanında Türkçe Terim Denemeleri," Yıllık- AÜ Basın-Yayın Yüksek Okulu VIII. 1983-1985, (Ankara: AÜ Siyasal Bilgiler Fakütesi ve Basın-Yayın Yüksek Okulu Basımevi, 1986), sayfa 145-168.

105. "Işletmecilik Alanında Türkçe Terim Denemeleri," Ankara Üniversitesi Siyasal Bilgiler Fakültesi Dergisi (Cilt XLI, Sayı 1-4, Ocak-Aralık 1986), (Ankara: AÜ Siyasal Bilgiler Fakültesi ve Basın-Yayın Yüksek Okulu Basımevi, 1987), sayfa 414-446.

106. "Kamu Yơnetimi Alanında Türkçe Terim Denemeleri," Yıllık IX: 19861987, A.Ü. BYYO. Ankara Üniversitesi'nin 40. Yılında Armağan (Ankara: AÜ Siyasal Bilgiler Fakültesi ve Basın-Yayın Yüksek Okulu Basımevi, 1987), sayfa 109-200.

107. Yönetim Sorunları (Ankara Üniversitesi Siyasal Bilgiler Fakültesi Yayınlan, No. 564) (A.Ü Siyasal Bilgiler Fakültesi ve Basın-Yayın Yüksek Okulu Basımevi, 1987), IX+ 248 sayfa.

108. "Devlet Personel Dairesinin Kuruluş Yıllan," Ankara Üniversitesi Siyasal Bilgiler Fakültesi Dergisi (Cilt XLII, Sayı 1-4, Ocak-Aralık 1987) (A.Ü. Siyasal Bilgiler Fakültesi ve Basın Yayın Yüksek Okulu Basımevi, 1987) sayfa $75-114$.

109. Türkiye'de Çă̆das Kamu Yönetimi Öğretiminin Başlangıç Yılları (Ankara Üniversitesi Siyasal Bilgiler Fakültesi Yayınlan: 568) (Ankara: A.Ü. Siyasal Bilgiler Fakültesi ve Basın-Yayın Yüksek Okulu Basımevi, 1988), XII+157 sayfa.

110. "Yine Devlet Planlama Örgütü'nün Kuruluşu Üzerine," Ankara Üniversitesi Siyasal Bilgiler Fakültesi Dergisi (Cilt XLIII, Sayı 1-2, Ocak-Haziran 1988) (A.Ü. Siyasal Bilgiler Fakültesi ve Basın-Yayın Yüksek Okulu Basımevi, 1988), sayfa 113-146.

111. Eğitimde Yörelerarası Dengesizliğin Neresindeyiz? 1965-1976-1987. (Ö̈̆renci Seçme ve Yerleştirme Merkezi yayını, Araşurma Geliştirme Birimi, AGB0016) (Ankara: METEKSAN Basımevi, 1989), 53 sayfa.

112. Görev Alma Yarışı- Işe Giriş Sınavları Üzerinde Karşılaştırmalı Bir Araştırma (Ar. Gör. Cahit Emre ile birlikte) (Ankara Üniversitesi Siyasal Bilgiler Fakültesi Yayınlarn: 572) (Ankara Üniversitesi Basımevi, 1990), XIV+215 sayfa. 
113. "Eğitim (Bilimleri) Fakültesi'nin Kuruluşu Üzerine," Eğitim Bilimleri Fakültesi Dergisi (Cilt 22, Sayı 1, 1989), sayfa 347-391.

114. "Batı Kaynaklı Sözcüklere Türkçe Karşlıklar," Ankara Üniversitesi Siyasal Bilgiler Fakültesi Dergisi (Cilt 46, Sayı 3-4, Haziran-Aralık 1991), sayfa 59. 85.

115. "Türk Dilinin Savunulması," Ankara Üniversitesi Siyasal Bilgiler Fakültesi Dergisi (Cilt 47, Sayı 3-4, Haziran-Aralk 1992), sayfa 237-270.

116. "Türetip Önerdiğimiz Søzcükler," Ankara Üniversitesi lletişim Fakültesi Ylllk' '92, sayfa 279-305.

117. Yönetimde Insan Ilişkileri (AÜ SBF Ders Notları 1990), Tıpkıbasım), 187 sayfa.

118. Yönetim Bilimine Giriş (AÜ SBF Ders Notları 1990, Tıpkıbasım), 97 sayfa.

119. "Dilimize Girenler," Ankara Üniversitesi Siyasal Bilgiler Fakültesi Dergisi (Cilt 48, Say1 1-4, Ocak-1993), sayfa 93-108.

120. Sözcüklerin Öyküsü (Ankara: T.C. Kütlür Bakanlığı, 1996), 539 sayfa.

121. Türk Hekimlik Dili (Ankara: T.C. Kültür Bakanlığı, 1997), xıı+466 sayfa.

Prof. Dr. Cemal Mıhçıoğlu'nun buraya konulmayan dil yazılarının büyük bir bölümü eski Türk Dil Kurumu'nun çıkardığı Türk Dili ilc Istanbul'da yayımlanan Çăgdaş Türk Dili dergilerinde yayımlanmışur. 